\title{
Can Serum Surfactant Protein D Levels be used as an Effective Factor Instead of Clinical Severity Scores of Pneumonia in Pediatric Emergency Departments?
}

\author{
Mehmet Açıkgöz' , Ahmet Güzel'1, Bülent Şişman, Adil Karadağ², Naci Murat', Şükrü Paksu' \\ 'Department of Pediatrics, Ondokuz Mayıs University School of Medicine, Samsun, Turkey \\ 2Department of Microbiology, Ondokuz Mayıs University School of Medicine, Samsun, Turkey \\ ${ }^{3}$ Department of Industrial Engineering, Ondokuz Mayıs University Engineering School, Samsun, Turkey \\ ${ }^{4}$ Clinic of Emergency, Sinop Atatürk State Hospital, Sinop, Turkey
}

\begin{abstract}
Aim: To investigate whether serum surfactant protein D (SP-D) level is an applicable indicator in differentiating bacterial and viral pneumonia and determining clinical severity in cases with community-acquired pneumonia (CAP).

Materials and Methods: A total of 67 subjects were analyzed prospectively; of these, 32 were patients (aged 1 month-18 years) with a diagnosis of CAP and 35 were healthy control subjects.

Results: The median age of the patients was 17.5 months (1.5-156 months). The serum SP-D levels of the patient group were significantly higher than those of the control group $(p<0.001)$. Based on the pneumonia clinical severity index, serum SP-D levels in patients with mild $(n=7)$, moderate $(n=19)$, and severe $(n=6)$ pneumonia were significantly higher than those in the control group $(p<0.001$, respectively). The serum SP-D levels in patients with severe pneumonia were much higher than in those with mild and moderate grades based the clinical severity index $(p<0.001$ and $p<0.001$, respectively). Although the serum SP-D levels in the bacterial pneumonia group were higher than those in the viral pneumonia group, the difference was not statistically significant
\end{abstract}

Conclusion: Although serum SP-D has limited efficacy in differentiating bacterial and viral pneumonia with respect to CAP in children, it can be used as an effective bioindicator for determining the clinical severity of the disease in emergency services. (Eurasian J Emerg Med 2016; 15: 1-6)

Keywords: Community acquired pneumonia, surfactant protein D, pneumonia clinical severity index, pediatric emergency

\section{Introduction}

Community-acquired pneumonia (CAP) in children is an important morbidity and mortality factor, especially in developing countries. According to data obtained from the World Health Organization (WHO), 156 million children under the age of five years are diagnosed with pneumonia each year. Twenty million of these children are hospitalized. More than two million are fatally affected $(1,2)$.

Usually, viral agents (20\%-43\%) are responsible for CAP etiology in children. Bacterial agents are a less significant factor (10\%-40\%) (3). However, many studies published in the last ten years have reported that mixed viral/bacterial infections play a role in $45 \%$ of pediatric CAP cases (4). Similar signs and symptoms caused by these agents result in the failure of radiological findings to differentiate the agents and difficulties in the routine practice of invasive interven- tions, such as hemoculture, bronchoalveolar lavage (BAL), and lung needle biopsy. Complications resulting from these interventions have encouraged clinicians to research diagnostic and prognostic biochemical indicators in CAP cases $(4,5)$. Furthermore, the unnecessary use of antibiotics due to failure to perform invasive interventions based on viral and bacterial pneumonia differentiation leads to financial burdens. Consequently, differentiation is another issue that emphasizes the importance of these bioindicators.

Surfactant protein D (SP-D) is a hydrophilic protein synthesized and secreted by alveolar epithelial type 2 and Clara cells as an acute phase reactant in lung infections (6). SP-D plays an important role in host defense by recognizing the carbohydrate structures in bacteria and viruses (7). According to experimental studies, it is secreted in inflammatory lung diseases, such as lung infection and pneumonitis. SP-D levels also increase due to the deterioration of alveolar cells $(8,9)$.

Correspondence to: Mehmet Açıkgöz e-mail: dracikgozm@gmail.com 
This study aimed to investigate whether serum SP-D levels can be used to determine clinical severity and differentiate bacterial/viral etiology in pediatric CAP cases.

\section{Materials and Methods}

Ethical approval for this prospective study was obtained from the Local Ethics Committee of Ondokuz Mayıs University in accordance with the Declaration of Helsinki. Written informed consent was obtained from relatives of the patients. A total of 67 subjects, including 32 patients between one month and 18 years of age, were presented to the Pediatric Emergency Service of the Medical School of Ondokuz Mayıs University due to a CAP diagnosis. Thirty-five age- and gender-matched control subjects were analyzed prospectively. The diagnosis of pneumonia was established according to the criteria determined by the WHO (10). Clinical severity scores were determined using the clinical severity index of Liu et al. (11), which is based on respiratory rate, retraction, the presence of dyspnea, and findings of auscultation (Table 1). To differentiate bacterial and viral pneumonia, modified parameters of the study conducted by Ruuskanen et al. (5) were used as pneumonia etiology prediction scores (Table 2). According to this scoring system, cases with scores $<3$ were evaluated to have viral etiology. Those with scores $\geq 3$ were evaluated to have bacterial etiology. The cri- teria of the guidelines of the British Thoracic Society were used in making hospitalization decisions (12). Patients were excluded from the study if they had a medical history of different diseases that may affect serum SP-D levels (including chronic pulmonary diseases such as cystic fibrosis, asthma, bronchiolitis obliterans, and bronchopulmonary dysplasia, as well as hepatic, renal, gastrointestinal, hematological, endocrinological, metabolic, neurological, or cardiovascular disorders). The control group consisted of healthy age- and gender-matched children.

The demographic characteristics, clinical, laboratory and radiological findings, serum SP-D levels, pneumonia clinical severity index results and patient treatment responses were evaluated. The correlation of other variables used for pneumonia clinical severity indexes, pneumonia etiology prediction scores with serum SP-D levels and C-reactive protein (CRP), leukocyte, sedimentation, neutrophil and lymphocyte counts, were analyzed.

\section{Collection of the Serum Samples and Measurement of Serum SP-D levels}

Serum samples were allowed to clot spontaneously at room temperature and were centrifuged at $3000 \times \mathrm{g}$ for $10 \mathrm{~min}$. All samples were stored at $-80^{\circ} \mathrm{C}$ pending analysis of serum SP-D. Serum SP-D levels were evaluated using ELISA (catalog no: RD194059101, BioVendor, European Union). Results were recorded in $\mathrm{ng} / \mathrm{mL}$.

Table 1. Clinical score for severity of pneumonia (11)

\begin{tabular}{|c|c|c|c|c|}
\hline \multirow[t]{2}{*}{ Variables } & \multicolumn{3}{|c|}{ Clinical score, circle one } & \multirow[b]{2}{*}{3 points } \\
\hline & \multirow[t]{2}{*}{0 point } & 1 point & 2 points & \\
\hline & & \multicolumn{2}{|c|}{ Respiratory rate* } & \\
\hline \multicolumn{5}{|l|}{ Age } \\
\hline$<2 \mathrm{~m}$ & & $\leq 60$ & $61-69$ & $\geq 70$ \\
\hline $2-12 \mathrm{~m}$ & & $\leq 50$ & $51-59$ & $\geq 60$ \\
\hline $13 \mathrm{~m}-2 \mathrm{y}$ & & $\leq 40$ & $41-44$ & $\geq 45$ \\
\hline $25 m-3 y$ & & $\leq 34$ & $35-39$ & $\geq 40$ \\
\hline $37 m-5 y$ & & $\leq 30$ & $31-34$ & $\geq 35$ \\
\hline $61 m-12 y$ & & $\leq 26$ & $27-30$ & $\geq 31$ \\
\hline$>12 y$ & & $\leq 23$ & $24-27$ & $\geq 28$ \\
\hline Retractions & None & Intercostal & Intercostal and substernal & $\begin{array}{l}\text { Intercostal, substernal, } \\
\text { and supraclavicular }\end{array}$ \\
\hline \multicolumn{5}{|l|}{ Dyspnea } \\
\hline $0-2 y$ & $\begin{array}{l}\text { Normal feeding, } \\
\text { vocalizations, } \\
\text { and activity }\end{array}$ & $\begin{array}{l}\text { Any } 1 \text { of the following: } \\
\text { difficulty in } \\
\text { feeding, decreased } \\
\text { vocalization, or agitation }\end{array}$ & $\begin{array}{l}\text { Any } 2 \text { of the following: } \\
\text { difficulty in feeding, } \\
\text { decreased vocalization, } \\
\text { or agitation }\end{array}$ & $\begin{array}{l}\text { Stops feeding, does not } \\
\text { vocalize, or is drowsy } \\
\text { or confused }\end{array}$ \\
\hline $25 m-5 y$ & $\begin{array}{c}\text { Normal feeding, } \\
\text { vocalizations, and play }\end{array}$ & $\begin{array}{l}\text { Any } 1 \text { of the following: } \\
\text { decreased appetite, } \\
\text { increased coughing after } \\
\text { play, or hyperactivity }\end{array}$ & $\begin{array}{l}\text { Any } 2 \text { of the following: } \\
\text { decreased appetite, } \\
\text { increased coughing } \\
\text { after play, and hyperactivity }\end{array}$ & $\begin{array}{c}\text { Stops eating or } \\
\text { drinking, stops playing, } \\
\text { or is } \\
\text { drowsy or confused }\end{array}$ \\
\hline$\geq 5 y$ & Counts till $\geq 10$ in one breath & Counts till 7-9 in one breath & Counts till 4-6 in one breath & Counts till $\leq 3$ in one breath \\
\hline Wheeze & $\begin{array}{l}\text { Normal breathing; no } \\
\text { wheezing present }\end{array}$ & $\begin{array}{l}\text { End-expiratory } \\
\text { wheeze only }\end{array}$ & $\begin{array}{l}\text { Expiratory wheeze only } \\
\text { (greater than end- } \\
\text { expiratory wheeze) }\end{array}$ & $\begin{array}{c}\text { Inspiratory and expiratory } \\
\text { wheeze, diminished } \\
\text { breath sounds, or both }\end{array}$ \\
\hline
\end{tabular}


Table 2. Clinical and laboratory variables used to distinguish viral pneumonia from bacterial pneumonia (pneumonia etiology prediction score) (5)

\begin{tabular}{|l|c|c|}
\hline Parametres & 0 point & 1 point \\
\hline Age & $<5$ years & $\geq 5$ years \\
\hline Clinical profile & Rhinitis, wheezing & $\begin{array}{c}>38.5^{\circ} \mathrm{C} \text { fever, } \\
\text { tachypnea }\end{array}$ \\
\hline $\begin{array}{l}\text { Total white blood } \\
\text { cell count }\end{array}$ & $\begin{array}{c}<15 \times 10^{9} \text { cells } \\
\text { per } \mathrm{L}\end{array}$ & $\begin{array}{c}\geq 15 \times 10^{9} \text { cells } \\
\text { per } \mathrm{L}\end{array}$ \\
\hline $\begin{array}{l}\text { Serum levels of } \\
\text { C-reactive protein }\end{array}$ & $<20 \mathrm{mg} / \mathrm{L}$ & $\geq 20 \mathrm{mg} / \mathrm{L}$ \\
\hline $\begin{array}{l}\text { Chest radiograph } \\
\text { findings }\end{array}$ & $\begin{array}{c}\text { Sole interstitial } \\
\text { infiltrates, bilaterally }\end{array}$ & $\begin{array}{c}\text { Lobar alveolar } \\
\text { infiltrates }\end{array}$ \\
\hline $\begin{array}{l}\text { Response to } \\
\text { antibiotic treatment }\end{array}$ & $\begin{array}{c}\text { Slow or } \\
\text { non-responsive }\end{array}$ & $\begin{array}{c}\text { Rapid (in three } \\
\text { days) }\end{array}$ \\
\hline Total score: $\geq 3$ suspected bacterial, $<3$ suspected viral & \\
\hline
\end{tabular}

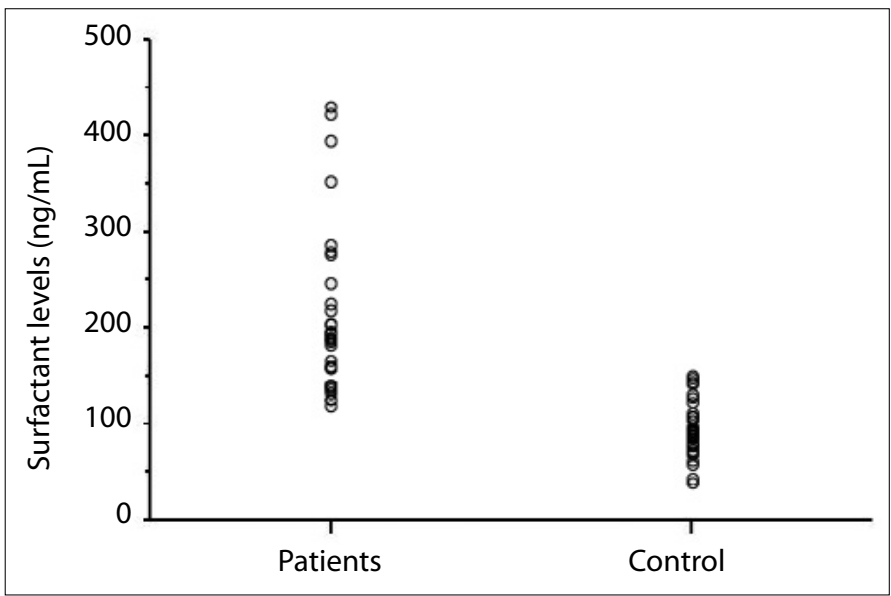

Figure 1. Comparison of serum SP-D levels between patient and control groups

\section{Statistical analysis}

All parameters were analyzed using the Statistical Package for the Social Sciences software version 21.0 (IBM SPSS Statistics; New York, USA). Control of normal data distribution was performed using the Shapiro-Wilks test. All categorical variables were represented as numbers and percentages, whereas numerical variables were given as mean \pm standard deviation and median (minumum-maximum). The normally distributed values of the patients and controls were compared using the independent $t$ test, while non-normally distributed data were analyzed using the Mann-Whitney $U$ and KruskalWallis tests. Pearson's chi-square test was used to analyze categorical data. Correlations between quantitative data were analyzed using the Spearman's correlation test. The accepted value for statistical significance was $\mathrm{p}<0.05$.

\section{Results}

The study included 67 total subjects, consisting of 35 healthy control subjects and 32 patients who applied to the Pediatric Emergency Service of our hospital with a CAP diagnosis. The median age of the patient group was 17.5 months (1.5 to 156 months), and the
Table 3. Comparison of serum SP-D levels in all study groups

\begin{tabular}{|c|c|c|c|}
\hline Groups & $\mathbf{n}$ & SP-D (ng/mL)* & $\mathbf{p}$ \\
\hline Control & 35 & $\begin{array}{c}93.79 \\
(39.66-154.27)\end{array}$ & \multirow[t]{2}{*}{$<0.001$} \\
\hline Patients & 32 & $\begin{array}{c}192.92 \\
(120.24-440.81)\end{array}$ & \\
\hline \multicolumn{4}{|c|}{ According to the SPS } \\
\hline LS & 7 & $\begin{array}{c}191.31^{\mathrm{A}} \\
(143.16-229.64)\end{array}$ & \multirow{3}{*}{0.001} \\
\hline MS & 19 & $\begin{array}{c}169.07^{A} \\
(120.24-282.09)\end{array}$ & \\
\hline HS & 6 & $\begin{array}{c}382.67^{B} \\
(285.30-440.81)\end{array}$ & \\
\hline \multicolumn{4}{|c|}{ According to the PEPS } \\
\hline Viral & 9 & $\begin{array}{c}132.59 \\
(39.66-282.09)\end{array}$ & \multirow[t]{2}{*}{0.133} \\
\hline Bacterial & 23 & $\begin{array}{c}198.22 \\
(120.24-440.81)\end{array}$ & \\
\hline \multicolumn{4}{|c|}{$\begin{array}{l}\text { *median (min-max), SP-D: surfactant protein D; LS: low score; MS: moderate sco- } \\
\text { re; HS: high score; SPS: severity of pnemonia score; PEPS: pneumonia etiology } \\
\text { prediction score. }\end{array}$} \\
\hline
\end{tabular}

median age of the control group was 24 months (1 to 156 months). The female/male ratio of the patient group was 1:13 (17/15), with a $1: 18(19 / 16)$ ratio in the control group. No difference was found between the groups with respect to median age value and gender $(p=0.183$ and $p=0.559$, respectively). 24 patients (75\%) received oxygen therapy during a follow-up period with a median duration of 2 days (between 0.5 and 27). One patient was intubated and hospitalized in the intensive care unit. 27 total patients applied with fever (84.3\%) for a median duration of two days (between one and nine days). All patients received antibiotics for a median duration of five days (between 2 and 42 days). Complications such as parapneumonic pleural effusion requiring no drainage, atelectasis, and respiratory acidosis were detected in 2 (6.2\%), 8 (25\%), and 11 (34.3\%) of the cases, respectively. The mean hospitalization duration of the patients was $11.72 \pm 8.25$ days ( 2 to 42 days).

Serum SP-D levels were significantly higher in the patient group than in the control group $(p<0.001)$ (Figure 1, Table 3). According to the pneumonia clinical severity index, serum SP-D levels in the groups with mild $(n=7)$, moderate $(n=19)$, and severe $(n=6)$ pneumonia were significantly higher than in the control group $(p<0.001$, $\mathrm{p}<0.001$, and $\mathrm{p}<0.001$, respectively) (Figure 2 and Table 3). While there was no significant difference between serum SP-D levels in cases with mild and moderate clinical severity $(p=0.461)$, serum SP-D levels in cases with a severe clinical index were remarkably higher than in cases with mild and moderate clinical severity $(p<0.001$ and $p<0.001$, respectively) (Figure 2 and Table 3). No significant correlation was found between clinical severity index and C-reactive protein (CRP) or thrombocyte and neutrophil counts $(p=0.942, p=0.328$, and $p=0.429$, respectively). Serum SP-D levels were higher in the groups with bacterial etiology. However, the difference was not statistically significant $(p=0.133)$ (Figure 3 and Table 3 ). A significant correlation $(r=0.482, p<0.001)$ was found between serum SP-D level and hospitalization duration in patients with bacterial etiology, whereas no sig- 


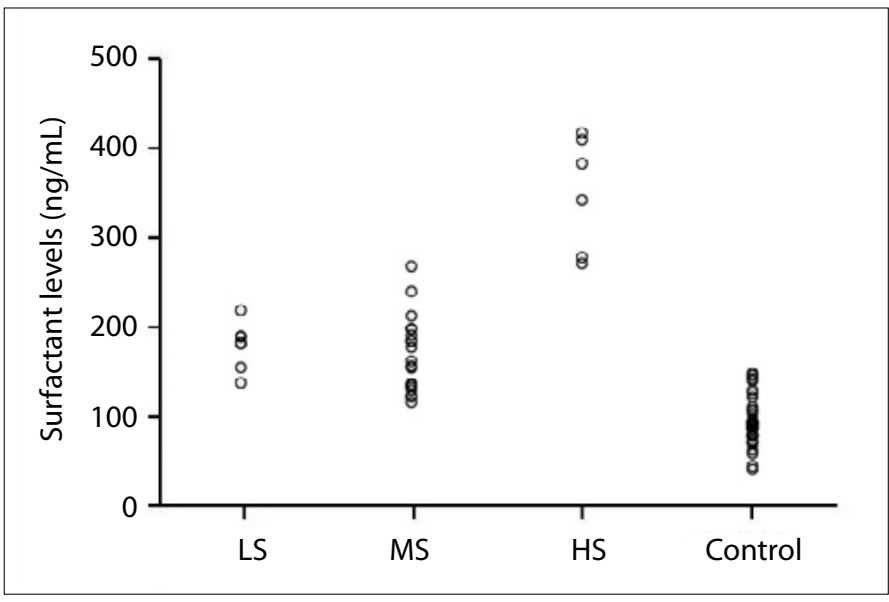

Figure 2. Comparison of serum SP-D levels according to pneumonia severity scores (LS: low score; MS: moderate score; HS: high score)

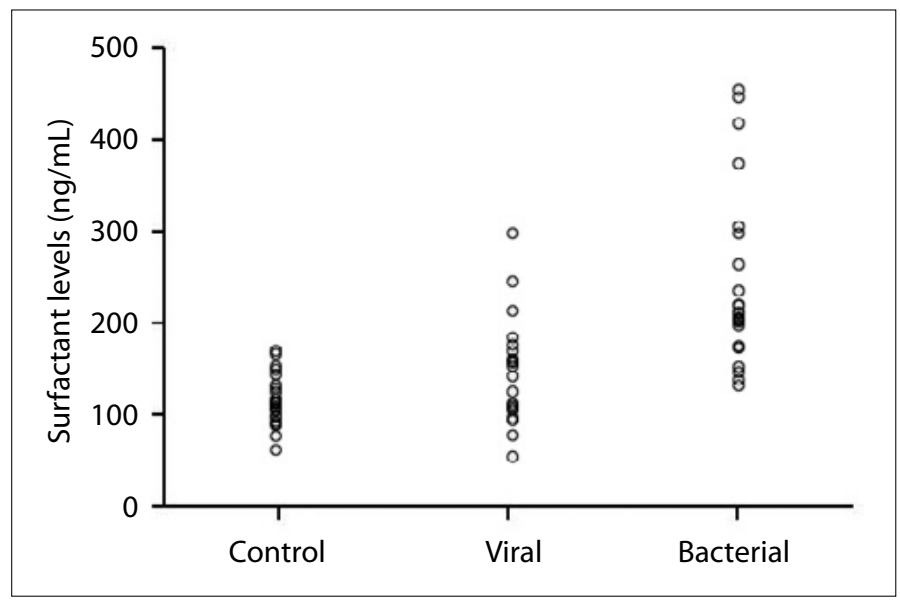

Figure 3. Comparison of serum SP-D levels according to pneumonia etiology prediction scores

Table 4. Comparison of clinical and laboratory findings in all patients according to pneumonia etiology prediction scores

\begin{tabular}{|c|c|c|c|}
\hline Variables & Bacterial $(n=23)$ & Viral $(n=9)$ & $\mathbf{p}$ \\
\hline Age, median (range) & 21 months (1.5-156) & 2.5 months (1.5-45) & 0.262 \\
\hline \multicolumn{4}{|l|}{ Gender } \\
\hline Male, n (\%) & $11(47.8)$ & $4(44.4)$ & 0.853 \\
\hline Female, n (\%) & $12(52.2)$ & $5(55.6)$ & \\
\hline Fever, (mean $\pm S D)$ & $37.10 \pm 0.78^{\circ} \mathrm{C}$ & $36.83 \pm 0.45^{\circ} \mathrm{C}$ & 0.331 \\
\hline Total white-blood cell count (mean \pm SD) & $13450 \pm 8041$ cells $/ L$ & $14081 \pm 7122$ cells $/ L$ & 0.838 \\
\hline Neutrophil count, (mean \pm SD) & $61.7 \pm 18.9 \%$ & $41.0 \pm 19.7 \%$ & 0.114 \\
\hline CRP, median (range) & $38.7 \mathrm{mg} / \mathrm{L}(0.5-270.0)$ & 15.0 mg/L (1.0-29.0) & 0.416 \\
\hline Wheezing, n (\%) & $7(30.4)$ & $6(66.7)$ & 0.109 \\
\hline Ral, n (\%) & $22(95.7)$ & $8(88.9)$ & 0.490 \\
\hline Retractions, n (\%) & $20(87.0)$ & $7(77.8)$ & 0.604 \\
\hline Nasal flaring, n (\%) & $19(82.6)$ & $6(66.7)$ & 0.370 \\
\hline Cyanosis, n (\%) & $5(21.7)$ & $1(11.1)$ & 0.648 \\
\hline Oxygen saturation, median (range) & $86.2 \%(43.0-99.6)$ & $82.7 \%(77.0-97.6)$ & 0.081 \\
\hline Oxygen therapy requirement, n (\%) & $19(82.6)$ & $5(55.6)$ & 0.176 \\
\hline Respiratory acidosis, n (\%) & $9(39.1)$ & $4(44.4)$ & 0.688 \\
\hline Intubation, n (\%) & $1(4.3)$ & - & \\
\hline \multicolumn{4}{|l|}{ Radiological findings } \\
\hline Sole interstitial infiltrates, bilaterally, n (\%) & $5(21.7)$ & $7(77.8)$ & 0.118 \\
\hline Lobar alveolar infiltrates, n (\%) & $11(47.8)$ & $1(11.1)$ & 0.109 \\
\hline Atelectasia, n (\%) & $7(30.4)$ & $1(11.1)$ & 0.386 \\
\hline Pleural effusion, n (\%) & $2(8.7)$ & - & \\
\hline Length of hospitalization, median (range) & $12(6-42)$ days & $6(2-10)$ days & $<0.001$ \\
\hline
\end{tabular}

nificant correlation was detected $(r=0.183, p=0.638)$ in patients with viral etiology. When the clinical, radiological, and laboratory findings were compared to pneumonia etiology prediction scores, a significant difference in hospitalization duration was detected between the bacterial and viral etiology groups $(p<0.001)$ (Table 4). No significant correlation was found between serum SP-D level and CRP, total WBC, or neutrophil count $(r=0.064, p=0.773 ; r=0.221, p=0.310$; and $r=0.339, p=0.114$, respectively). 


\section{Discussion}

This study investigated the efficacy of serum SP-D levels in predicting clinical severity, prognosis, and pneumonia etiology in children with CAP who were presented at our Pediatric Emergency Service.

Serum surfactant protein is a hydrophilic protein from the collectin family, secreted by alveolar epithelial type 2 and Clara cells in the lung tissue (6). SP-D is secreted as an acute phase reactant, especially in the presence of infectious agents; it plays a role in host defense mechanisms via adhesion to micro-organisms due to its hydrophilic nature $(6,7)$, is important in aggregation, neutralization, and opsonization during phagocytosis, results in direct gram-negative bacterial cell-membrane lysis, inhibiting bacterial/fungal growth in macrophages, and has a aggregation-independent manner $(7,13)$. Therefore, SP-D is an important biomarker of infectious pulmonary diseases. Studies have shown that it plays an important role in host defense against viral and bacterial CAP agents, such as Klebsiella pneumoniae $(14,15)$, Haemophilus influenza $(14,16)$, Streptococcus pneumoniae $(14,17)$, Mycoplasma pneumoniae $(14,18)$, and influenza A virus $(14,19)$.

Etiology clarification (bacterial or viral) in CAP cases is important for pneumonia management. Despite advanced diagnostic tests, a clinical algorithm has not yet been developed to clarify etiology in the child age group. Specifically, high coinfection rates (30 to 45\%) accompanying viral CAP cases increase the difficulty of this situation $(4,5)$. Unclarified CAP etiology is critical, since it leads to unnecessary use of antibiotics, elevated resistance, and increased health care expenses. Diagnostic difficulties in CAP cases generally necessitate the evaluation of multiple factors to differentiate viral and bacterial etiology, such as patient age, disease progression, accompanying symptoms, serum biomarkers, serum acute phase reactants, radiological findings, presence of viral epidemics, and clinical response to antibiotics (5). For that purpose, the British Thoracic Society has emphasized that viral pneumonia should be considered in the presence of a fever under $38.5^{\circ} \mathrm{C}$, wheezing, a respiratory rate below $50 / \mathrm{min}$, and striking chest recession for children under five years old (20). In our study, we used the scores of the variables identified by Ruuskanen et al. (5) to differentiate viral and bacterial pneumonia and investigate whether serum SP-D value can be used solely as a marker in this etiological differentiation.

The markers used in biomarker studies of CAP cases include inflammatory indicators such as CRP, WBC, ESR, procalcitonin, IL-6, and TNF- $a(5,21,22)$. The conclusions of studies vary with respect to the success of these inflammatory indicators in predicting clinical severity in patients diagnosed with pneumonia. Serum WBC, CRP, and procalcitonin levels are the most widely studied acute phase reactants in child and adult CAP cases (5). The literature has demonstrated significantly higher levels in subjects with bacterial pneumonia, though this indication does not show sufficient specificity or sensitivity when used exclusively (5). Another study conducted by Christ-Crain et al. (23) revealed that C-reactive peptide (CRP) does not show a significant difference in pneumonia cases with different severity degrees assessed by PSI. However, CRP has been identified as a serum marker in predicting bacterial pneumonia in another study conducted by the Pediatric Emergency Service (24). Kolling et al. (25) have shown that IL-1 $\beta$ levels in CAP patients are not correlated with inflammatory markers, such as WBC and CRP, in contrast to IL-1ra and TNF-a.
However, IL-1 $\beta$ levels are more correlated with clinical pulmonary infection scores. These studies have stated that ESR and WBC, as well as the other acute phase reactants, are most commonly used in clinical practice to demonstrate moderate sensitivity and specificity as well as low diagnostic efficacy $(22,26-28)$. In this study, no significant correlation was found between the clinical severity index and CRP, WBC, and neutrophil compatibly. However, these markers were observed to be statistically significant in the differentiation of viral and bacterial pneumonia.

In recent years, experimental studies have emphasized that specific pulmonary bioindicators considered to be secreted from deteriorated lung tissue, such as surfactant protein A (SP-A), surfactant protein D (SP-D), Krebs von den Lungren-6 (KL-6), and Clara cell protein (CC-16), are effective in determining lung deterioration severity (29-31).

In a study on adult CAP cases, Leth-Larsen et al. (14) reported that they could only determine the agent in 22 (36\%) of 61 CAP cases. Furthermore, they detected that serum SP-D levels were higher in pneumonia cases with atypical etiology than in pneumonia cases associated with Streptococcus pneumoniae and Haemophilus influen$z a$ as etiological agents, in contrast to CRP and WBC, according to etiological detection results in these cases. A study by Ichiyasu et al. (31) on 48 cases of bronchopneumonia with or without chronic asthma in an age group ranging from two to four years revealed that serum SP-D levels were higher in severe cases requiring intensive care. In another study on 53 cases with RSV bronchiolitis with or without chronic heart disease, Mosbah et al. (32) detected that serum SP-D levels were higher in the patient group, which required mechanical ventilation support and oxygen requirements. These two studies indicate that serum SP-D level increases in severe pulmonary infection with either bacterial or viral etiology. In addition, Shu et al. (33) suggest investigating the correlation between lung involvement and serum SP-D levels. Their study on serum SP-D levels in 47 CAP cases attributes this conclusion to the fact that Mycoplasma pneumoniae in children correlates to SP-D levels detected by BAL and increases significantly when accompanied by severe lung involvement. This study indicates the validity of using serum SP-D levels rather than interventional diagnostic methods such as BAL to differentiate lung infection etiology. Our research revealed that serum SP-D levels increase according to lung infection severity. This is compatible with the literature concerning viral and bacterial etiology cases. Nevertheless, research has established that the SP-D level increase in CAP cases with bacterial etiology was higher than in cases with viral etiology. However, this difference was not statistically significant.

\section{Study limitations}

This study had several limitations. For example, it was conducted at one referral center with a limited number of patients over a short time period.

\section{Conclusion}

Serum SP-D levels in children are applicable biomarkers that can help to predict severity in CAP cases applying to pediatric emergency services. Furthermore, prospective studies must be conducted on larger case series. A higher increase in serum SP-D levels in cases of bacterial pneumonia is demonstrated; however, clinical applications related to differentiating bacterial and viral pneumonia are limited. 
Ethics Committee Approval: Ethics committee approval was received for this study from the ethics committee of Ondokuz Mayıs University School of Medicine.

Informed Consent: Written informed consent was obtained from patients who participated in this study.

Peer-review: Externally peer-reviewed.

Conflict of Interest: No conflict of interest was declared by the authors.

Financial Disclosure: The authors declared that this study has received no financial support.

\section{References}

1. Esposito S, Principi N. Pneumococcal vaccines and the prevention of community-acquired pneumonia. Pulm Pharmacol Ther 2014; 1094: 31-5.

2. Rudan I, Boschi-Pinto C, Biloglav Z, Mulholland K, Campbell H. Epidemiology and etiology of childhood pneumonia. Bull World Health Organ 2008; 86: 408-16. [CrossRef]

3. Tejani NR. Respiratory Disorders Bacterial pneumonia. In: Binita R. Shah, eds, Atlas of pediatric emergency. 2th ed. New York: The McGraw-Hill Companies, 2013; 205-8.

4. Cardinale F, Cappiello AR, Mastrototaro MF, Pignatelli M, Esposito S. Community-acquired pneumonia in children. Early Hum Dev 2013; 89: 49-52. [CrossRef]

5. Ruuskanen O, Lahti E, Jennings LC, Murdoch DR. Viral pneumonia. Lancet 2011; 377: 1264-75. [CrossRef]

6. Haagsman HP, Hogenkamp A, van Eijk M, Veldhuizen EJ. Surfactant collectins and innate immunity. Neonatology 2008; 93: 288-94. [CrossRef]

7. Kotecha S, Doull I, Davies P, McKenzie Z, Madsen J, Clark HW, et al. Functional heterogeneity of pulmonary surfactant protein- $D$ in cystic fibrosis. Biochim Biophys Acta 2013: 2391-400.

8. Guzel A, Kanter M, Guzel A, Yucel AF, Erboga M. Protective effect of curcumin on acute lung injury induced by intestinal ischaemia/reperfusion. Health 2013; 29: 969. [CrossRef]

9. Guzel A, Kanter M, Guzel A, Pergel A, Erboga M. Anti-inflammatory and antioxidant effects of infliximab on acute lung injury in a rat model of intestinal ischemia/reperfusion. J Mol Histol 2012; 43: 361-9. [CrossRef]

10. World Health Organization: The Management of Acute Respiratory Infections in Children. Practical Guidelines for Outpatient Care. Geneva: World Health Organization; 1995.

11. Liu LL, Gallaher MM, Davis RL, Rutter CM, Lewis TC, Marcuse EK. Use of a respiratory clinical score among different providers. Pediatr Pulmonol 2004; 37: 243-8. [CrossRef]

12. Harris M, Clark J, Coote N, Fletcher P, Harnden A, McKean M, et al. British Thoracic Society guidelines for the management of community acquired pneumonia in children: update 2011. Thorax 2011; 66(Suppl 2): ii1-23.

13. Sorensen $\mathrm{GL}$, Husby $\mathrm{S}$, Holmskov U. Surfactant protein $A$ and surfactant protein D variation in pulmonary disease. Immunobiology 2007; 212: 381-416. [CrossRef]

14. Leth-Larsen R, Nordenbaek C, Tornoe I, Moeller V, Schlosser A, Koch C, et al. Surfactant protein D (SP-D) serum levels in patients with community-acquired pneumonia. Clin Immunol 2003; 108: 29-37. [CrossRef]

15. Lim BL, Wang JY, Holmskov U, Hoppe HJ, Reid KB. Expression of the carbohydrate recognition domain of lung surfactant protein $D$ and demonstration of its binding to lipopolysaccharides of gram-negative bacteria, Biochem. Biophys Res Commun 1994; 202: 1674-80. [CrossRef]
16. LeVine AM, Whitsett JA, Gwozdz JA, Richardson TR, Fisher JH, Burhans $M S$, et al. Distinct effects of surfactant protein $A$ or $D$ deficiency during bacterial infection on the lung, J Immunol 2000; 165: 3934-40.

17. Hartshorn KL, Crouch E, White MR, Colamussi ML, Kakkanatt A, Tauber B, et al. Pulmonary surfactant proteins $A$ and $D$ enhance neutrophil uptake of bacteria. Am J Physiol 1998; 274: 958-69.

18. Chiba H, Pattanajitvilai S, Evans AJ, Harbeck RJ, Voelker DR. Human Surfactant Protein D (SP-D) binds Mycoplasma pneumoniae by high affinity interactions with lipids. J Biol Chem 2002; 277: 20379-85. [CrossRef]

19. Hartshorn KL, Crouch EC, White MR, Eggleton P, Tauber Al, Chang D, et al. Evidence for a protective role of pulmonary surfactant protein D (SP-D) against influenza A viruses. J Clin Invest 1994; 94: 311-9. [CrossRef]

20. British Thoracic Society of Standards of Care Committee. BTS guidelines for the management of community acquired pneumonia in childhood. Thorax 2002; 57: 1-24.

21. Lin WC, Lu SL, Lin CF, Chen CW, Chao L, Chao J, et al. Plasma kallistatin levels in patients with severe community-acquired pneumonia. Crit Care 2013; 17: R27.

22. Virkki R, Juven T, Rikalainen H, Svedström E, Mertsola J, Ruuskanen O. Diff erentiation of bacterial and viral pneumonia in children Thorax 2002; 57 : 438-41.

23. Christ-Crain M, Morgenthaler NG, Stolz D, Müller C, Bingisser R, Harbarth $\mathrm{S}$, et al. Pro-adrenomedullin to predict severity and outcome in community-acquired pneumonia. Critical Care 2006; 10: 96-104. [CrossRef]

24. Marcus N, Mor M, Amir L, Mimouni M, Waisman Y. Validity of the quick-read C-reactive protein test in the prediction of bacterial pneumonia in the pediatric emergency department. Eur J Emerg Med 2008; 15: 158-61. [CrossRef]

25. Kolling UK, Hansen F, Braun J, Rink L, Katus HA, Dalhoff K. Leucocyte response and anti-inflammatory cytokines in community acquired pneumonia. Thorax 2001; 56: 121-5. [CrossRef]

26. Korppi M, Heiskanen-Kosma T, Jalonen E, Saikku P, Leinonen M, Halonen $\mathrm{P}$, et al. Aetiology of community-acquired pneumonia in children treated in hospital. Eur J Pediatr 1993; 152: 24-30. [CrossRef]

27. Moulin F, Raymond J, Lorrot M, Marc E, Coste J, Iniguez JL, et al. Procalcitonin in children admitted to hospital with community acquired pneumonia. Arch Dis Child 2001; 84: 332-6. [CrossRef]

28. Korppi M. Non-specific host response markers in the differentiation between pneumococcal and viral pneumonia: what is the most accurate combination? Pediatr Int 2004; 46: 545-50.

29. Kropski JA, Fremont RD, Calfee CS, Ware LB. Clara cell protein (CC16), a marker of lung epithelial injury, is decreased in plasma and pulmonary edema fluid from patients with acute lung injury. Chest 2009; 135: 1440-7. [CrossRef]

30. Arai Y, Obinata K, Sato Y, Hisata K, Tadokoro R, Tawa T, et al. Clinical significance of the serum surfactant protein $\mathrm{D}$ and KL- 6 levels in patients with measles complicated by interstitial pneumonia. Eur J Pediatr 2001; 160: 425-9. [CrossRef]

31. Ichiyasu H, Ichikado K, Yamashita A, Iyonaga K, Sakamoto O, Suga M, et al. Pneumocyte biomarkers KL- 6 and surfactant protein $D$ reflect the distinct findings of high-resolution computed tomography in nonspecific interstitial pneumonia. Respiration 2012; 83: 190-7. [CrossRef]

32. Mosbah AA, Abdellatif NA, Sorour El, Awadallah MF. Serum SP-D levels as a biomarker of lung injury in children suffering of bronchopneumonia. $J$ Egypt Soc Parasitol 2012; 42: 25-32. [CrossRef]

33. Kawasaki Y, Endo K, Suyama K, Sato M, Ito M, Hashimoto K, et al. Serum SP-D levels as a biomarker of lung injury in respiratory syncytial virus bronchiolitis. Pediatr Pulmonol 2011; 46: 18-22. [CrossRef]

34. Shu LH, Shang YX, Cai XX, Zhang H, Li M, Zhou QL, et al. Changes to surfactant proteins in the bronchoalveolar lavage fluid and serum of children with Mycoplasma pneumoniae pneumonia. Zhongguo Dang Dai Er Ke Za Zhi 2012; 14: 928-32. 